\title{
T cell-mediated immune response to respiratory coronaviruses
}

\author{
Rudragouda Channappanavar · Jincun Zhao • \\ Stanley Perlman
}

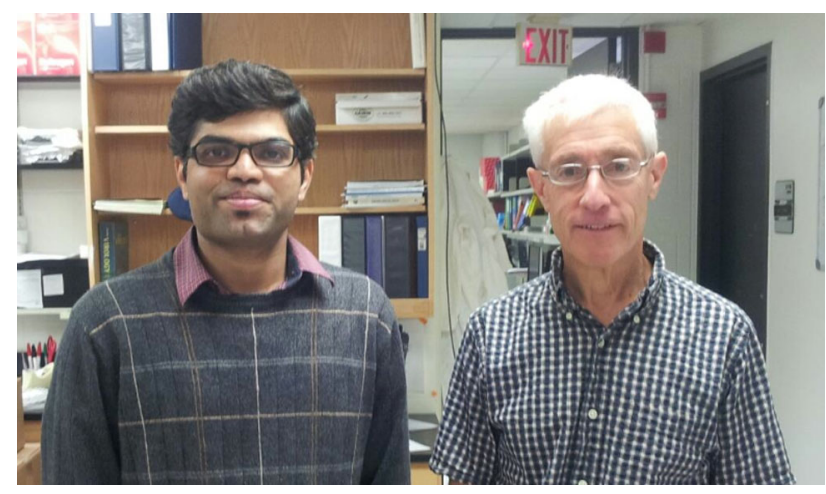

Rudragouda Channappanavar Stanley Perlman

Published online: 21 May 2014

(C) Springer Science+Business Media New York 2014

\begin{abstract}
Emerging respiratory coronaviruses such as the severe acute respiratory syndrome coronavirus (SARS-CoV) and Middle East respiratory syndrome coronavirus (MERS-CoV) pose potential biological threats to humans. SARS and MERS are manifested as severe atypical pneumonia associated with high morbidity and mortality in humans. The majority of studies carried out in SARS-CoV-infected humans and animals attribute a dysregulated/exuberant innate response as a leading contributor to SARS-CoV-mediated pathology. A decade after the 2002-2003 SARS epidemic, we do not have any approved preventive or therapeutic agents available in case of re-emergence of SARS-CoV or other related viruses. A strong neutralizing antibody response generated against the spike (S) glycoprotein of SARS-CoV is completely protective in the susceptible host. However, neutralizing antibody titers and the memory B cell response are short lived in SARSrecovered patients and the antibody will target primary homologous strain. Interestingly, the acute phase of SARS in humans is associated with a severe reduction in the number of T cells in the blood. Surprisingly, only a limited number of studies have explored the role of the T cell-mediated adaptive immune response in respiratory coronavirus pathogenesis. In this review, we discuss the role of anti-virus CD4 and CD8 T cells during respiratory coronavirus infections with a special emphasis on emerging coronaviruses.
\end{abstract}

Keywords Respiratory coronavirus $\cdot \mathrm{T}$ cells $\cdot$ Immune response

\section{Introduction}

Coronaviruses belong to the family coronaviridae and are enveloped, positive-sense, single-stranded RNA viruses. The coronavirus genome is approximately $31 \mathrm{~kb}$, making these viruses the largest known RNA viruses yet identified [1]. Coronaviruses infect a variety of hosts including humans and several other vertebrates. Coronaviruses are associated with several respiratory and intestinal tract infections. Respiratory coronaviruses have long been recognized as significant pathogens in domestic and companion animals and as the cause of upper respiratory tract infections in humans [2]. Thus, several human coronaviruses (HCoVs) are

R. Channappanavar $\cdot$ J. Zhao $\cdot$ S. Perlman $(\bowtie)$

Department of Microbiology, Carver College of Medicine,

The University of Iowa, Iowa City, IA 52242, USA

e-mail: stanley-perlman@uiowa.edu the etiological agents for mild respiratory illness, including the common cold and croup (e.g., HCoV-229E, HCoVOC43, HCoV-NL63 and HCoV-HKU) [3, 4]. Human coronaviruses such as SARS-CoV and MERS-CoV are also associated with severe respiratory illness [5-9]. Coronaviruses that induce respiratory tract disease in other vertebrate animals include mouse hepatitis virus-1 (MHV-1) a natural mouse pathogen, infectious bronchitis virus (IBV) in chickens and other avian species, bovine coronavirus $(\mathrm{BCoV})$ in cows and other ruminants, porcine respiratory syndrome virus (PRCV) in pigs and canine respiratory coronavirus (CRCoV) in dogs to name a few $[10,11]$.

Coronaviruses that induce mild respiratory illness are generally more prevalent in younger populations of humans and domestic animals $[10,11]$, while those that are responsible for severe disease, such as SARS-CoV and MERS$\mathrm{CoV}$, cause lethal disease in aged or immunocompromised individuals $[8,12]$. Notable exceptions to this are IBV, a 
severe form of upper respiratory tract infection in young chicks [13], and HCoV-NL63, responsible for croup in children [14]. During the 2002-2003 epidemic, SARS-CoV infection resulted in an overall $10 \%$ mortality. While $100 \%$ survival was observed in young $(<24$ years old) SARS-CoVinfected patients, the mortality rate was $>50 \%$ in elderly individuals aged 65 and above [11]. To date, newly emerging MERS-CoV has infected 495 people with 141 deaths [15]. Several reports from the 2002-2003 SARS outbreak indicated that the acute respiratory distress syndrome (ARDS) developed in the majority of patients with severe disease. ARDS, a nonspecific end-stage process in patients with pulmonary disease caused by a variety of etiological agents, is most severe in elderly individuals and resulted in $\sim 52 \%$ mortality among elderly SARS patients [16]. Pathological investigation of patients with lethal SARS revealed acute pulmonary edema, extensive inflammatory cell infiltration, multi-organ failure, thromboembolic complications and septicemia [17]. Severe lung and systemic inflammation is believed to result from cytokine dysregulation; in patients with SARS, increased levels of cytokines such as TNF- $\alpha$, IP10, IL-6 and IL-8 likely contributed to the poor outcome [17]. Such an exuberant innate cytokine response was attributed to hyper-activation of macrophage/monocyte lineage cells. Additionally, increased levels of type I interferon (IFN) and a dysregulated interferon-stimulated gene (ISG) response were observed in patients with severe SARS $[18,19]$. Overall, it is still not known whether SARS in humans was the result primarily of type I IFN-independent exaggerated pro-inflammatory reaction or whether both IFNdependent and IFN-independent aberrant cytokine production contributed to severe pathology. Similar to SARS in humans, MERS-CoV-infected patients exhibit symptoms of a flu-like illness followed by an atypical pneumonia, including fever, dry cough and severe shortness of breath [8]. However, we still do not know much about the innate or the adaptive immune response in MERS-CoV-infected individuals, mainly because only a small number of sporadic MERS cases reported to date, and there is a paucity of clinical data absence of any autopsy information.

To investigate SARS-CoV pathogenesis, several animal models have been developed $[20,21]$. Soon after the 2002-2003 SARS epidemic, mice, cats and ferrets were used as animal models to study SARS pathogenesis. Human isolates of SARS-CoV could replicate in these hosts following intranasal infection, but in contrast to SARS in humans, no overt clinical signs were observed in cats while $50 \%$ of ferrets showed evidence of mild disease [22]. Similarly, mice infected with the human Urbani strain of SARS-CoV developed only mild disease, although disease severity was greater in aged mice [23]. Several nonhuman primates were also experimentally infected with SARS-CoV with variable disease severity dependent upon the primate model used [7, 21, 24]. Despite this variation, aged non-human primates were associated with exacerbated innate immune response and acute lung injury, similar to that in humans although without associated lethality [7, 21]. Because of this lack of useful animal models that mimicked human disease, several laboratories developed mouse- or rat-adapted strains of SARS-CoV that caused extensive and lethal pulmonary disease. One mouse-adapted strain of SARS-CoV, MA15, has been extensively used in pathogenesis studies. SARS-CoVMA15 induces severe disease in young BALB/C and in aged mice ( $>20$ weeks) of all strains [25]. Infection of aged mice with SARS-CoV-MA15 induced a robust up-regulation of pro-inflammatory cytokines (TNF-a, IL-6, IL-8, IP10, MCP-1) and chemokines (CXCL-1, CXCL-2, CCL-3 and CCL-5) $[21,26]$. Furthermore, in comparison with SARS-CoV-MA15-infected young C57BL/6 mice, infection of aged mice ( $>12$ months) is associated with severe reduction in the number of virus-specific CD8 T cells in the lungs [27]. Since $T$ cells are required for controlling exuberant innate immune responses, the absence of a potent anti-virus $\mathrm{T}$ cell response in aged hosts could lead to exacerbated/dysregulated innate responses and pathology [28, 29]. Additionally, virus-specific CD4 and CD8 T cells play a critical role in clearing virus by eliminating virusinfected cells. Several studies in both humans and animals have identified and discussed the host innate response to SARS-CoV and other respiratory coronaviruses. Despite these extensive efforts, there is limited information available on the role of the antigen-specific $\mathrm{T}$ cell-mediated immune response to respiratory coronaviruses. In this review, we will focus on the $\mathrm{T}$ cell-mediated immune response to SARS-CoV.

\section{Primary T-cell response to respiratory virus infections}

The majority of studies addressing $\mathrm{T}$ cell responses to respiratory virus infections come from mice infected with a variety of natural and mouse-adapted pathogens. A few studies use natural mouse pathogens such as Sendai virus, a mouse para-influenza type I pathogen and mouse hepatitis virus-1 (MHV-1). More commonly, mouse-adapted stains of human pathogens such as the A/Puerto Rico/8/1934 H1N1 (PR8) or A/WSN/33 H1N1 (WSN) strains of influenza and SARS-CoV-MA15 have been used to study innate and adaptive immune responses [25, 30]. Initiation of the immune response against invading pathogens begins with direct infection of airway epithelium. Following initial infection, lung-resident respiratory dendritic cells (rDCs) acquire the invading pathogen or antigens from infected epithelial cells, become activated, process antigen and migrate to the draining (mediastinal and cervical) lymph 

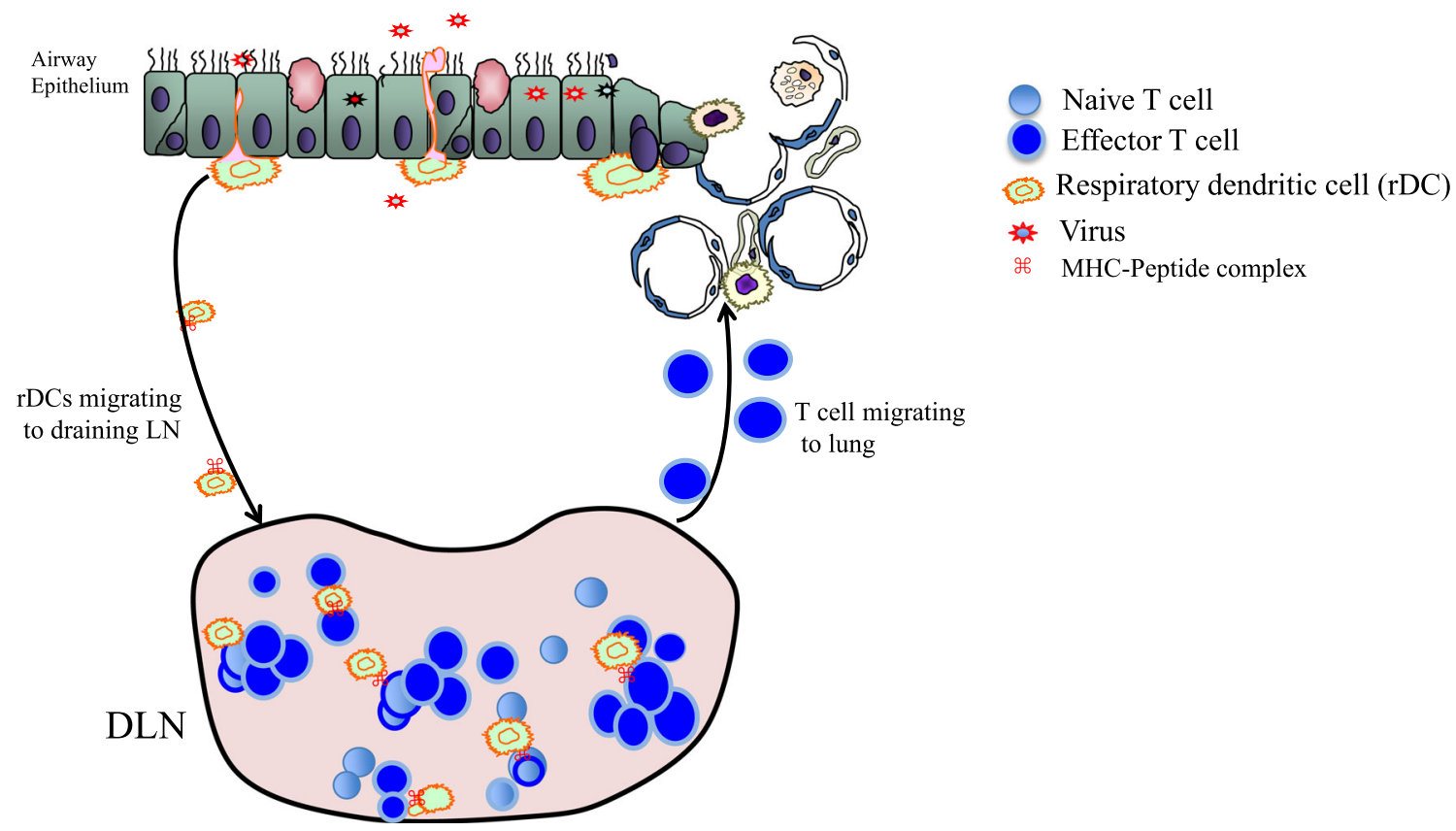

Fig. 1 Induction of $\mathrm{T}$ cell response to respiratory virus infection

nodes (DLN). Once in the DLNs, rDCs present the processed antigen in the form of $\mathrm{MHC} /$ peptide complex to naïve circulating $\mathrm{T}$ cells. Following engagement of the $\mathrm{T}$ cell receptor (TCR) with peptide-MHC complex and additional co-stimulatory signals, $\mathrm{T}$ cells become activated, proliferate vigorously and migrate to the site of infection [31-33] (Fig. 1). Once at the site of infection, activated virus-specific effector $\mathrm{T}$ cells produce antiviral cytokines (IFN- $\gamma$, TNF- $\alpha$, IL-2), chemokines (CXCL-9, 10 and 11) and cytotoxic molecules (perforin and granzyme B) [34]. Effector cytokines such as IFN- $\gamma$ directly inhibit viral replication and enhance antigen presentation [35]. The chemokines produced by activated $\mathrm{T}$ cells recruit more innate and adaptive cells to control pathogen burden. Cytotoxic molecules such as granzyme B directly kill infected epithelial cells and help eliminate the pathogen [36-39]. Despite a wealth of information on the $\mathrm{T}$ cell response to many respiratory pathogens, less is known about the respiratory coronavirus infections.

Virus-specific T cells and the primary immune response to SARS-CoV in humans

The acute phase of SARS in human patients was associated with marked leukopenia with severe lymphopenia ( $80 \%$ of patients), involving a dramatic loss of CD4 $\mathrm{T}$ cells ( 90-100\% of patients) and CD8 T cells ( 80-90\% patients) in comparison with healthy control individuals
[40-42]. Subsequent studies showed impaired CD4 and $\mathrm{CD} 8 \mathrm{~T}$ cell activation in SARS-CoV-infected patients as determined by CD25, CD28 and CD69 expression on CD4 and CD8 $\mathrm{T}$ cell subsets [43, 44]. Severe SARS-CoV infection in humans was characterized by the delayed development of the adaptive immune response and prolonged virus clearance [45]. In addition, leukopenia and associated lymphopenia are also observed in MERS patients, albeit to a lesser degree than that observed in SARS patients. A detailed clinical study showed that $14 \%$ of MERS patients were leukopenic, while $34 \%$ of the patients had lymphopenia [46]. Decreased numbers of $\mathrm{T}$ cells strongly correlated with the severity of acute phase of SARS disease in humans $[42,47]$. Although SARS-CoV is not known to productively infect $\mathrm{T}$ cells, altered antigen presenting cell (APC) function and impaired DC migration resulting in reduced priming of $\mathrm{T}$ cells likely contribute to fewer number of virus-specific T cells in the lungs [27, 48, 49]. Other possible explanations for $\mathrm{T}$ cell lymphopenia include an exuberant type I IFN response and high levels of glucocorticoids resulting from a normal stress response both of which might induce $\mathrm{T}$ cell apoptosis [50]. Currently, much less is known about the fate of $\mathrm{T}$ cells in MERS-CoV-infected patients.

Several HLA-A*02:01-restricted $\mathrm{T}$ cells recognizing SARS-CoV epitopes have been identified in the PBMC of SARS-recovered individuals. Most of these immunogenic epitopes were localized to the spike (S) and nucleocapsid 
(N) protein of SARS-CoV, using ELISPOT and intracellular IFN- $\gamma$ expression assay following peptide stimulation directly ex vivo [51, 52]. Additionally, several CD8 T cell epitopes were also identified and characterized in the $M$ protein of SARS-CoV from PBMCs of the SARS survivors; however, HLA restriction of these is not known [53]. Subsequently, Lv et al. [54] demonstrated that immunization of HLA-A2.1/Kb transgenic mice with a recombinant DNA (rDNA) vaccine encoding the $\mathrm{S}$ protein induced peptide S958-966-specific IFN- $\gamma$ release and target cell lysis by CD8 T cells. Several SARS-CoV specific T cell epitopes were identified in infected/recovered human PBMCs $[55,56]$. To date, few studies have identified antigen-specific CD4 $\mathrm{T}$ cells in SARS-CoV-infected/ recovered patients. In one of the studies, CD4 T cells specific for epitopes in the nucleocapsid $(\mathrm{N})$ protein were identified in SARS survivors [57]. In the other study, Libraty et al. [58] detected HLA-DR restricted CD4 T cell epitopes in the S protein (S729-745, S358-374 and S427-444) in recovered patients. These results show that both $\mathrm{S}$ and $\mathrm{N}$ proteins of SARS-CoV contain immunogenic epitopes that can be recognized by CD4 and CD8 T cells. Since the $\mathrm{S}$ protein of SARS-CoV is capable of inducing neutralizing antibodies, CD4 and CD8 $\mathrm{T}$ responses and $\mathrm{N}$ protein can elicit $\mathrm{T}$ cell response in humans, both of these proteins are useful potential vaccine candidates able to generate a strong humoral and cell-mediated immune response against SARS-CoV. One caveat is that immunizations with some vaccines encoding the $\mathrm{N}$ protein induce an eosinophilic response [59], so these vaccines will need to be monitored carefully. No information about epitopes recognized in patients with MERS is currently available.

The $\mathrm{T}$ cell response in respiratory coronavirus infected animals

\section{Identification of virus-specific CD4 and CD8 T cell epitopes in mice}

In one of the first studies, Yang et al. [60] demonstrated the existence of SARS-CoV-specific T cells in mice immunized with recombinant DNA (rDNA) encoding the $\mathrm{S}$ protein. After stimulation with pools of overlapping S-peptides, antigen-specific CD4 and CD8 T cells were detected by IFN- $\gamma$ expression. Subsequently, several studies have identified SARS-CoV-specific CD4 and CD8 T cells in mice immunized with rDNA or recombinant virus encoding S, $\mathrm{N}$ or $\mathrm{M}$ proteins. [61-64]. A detailed list of SARS-CoV-specific immunodominant CD4 and CD8 T cell epitopes identified in mice is provided in Table 1.

Identification of relevant $\mathrm{T}$ cell epitope in MERS-CoV has been hindered by the absence, until recently of a mouse model for infection. Dipeptidyl-peptidase (hDPP4) is
Table 1 List of SARS-CoV-specific CD4 and CD8 T cell epitopes found in C57BL/6 and BALB/C mice

\begin{tabular}{|c|c|c|c|}
\hline Protein & Peptide sequence & MHC-restriction & References \\
\hline \multicolumn{4}{|c|}{ CD8 T cell epitopes } \\
\hline \multicolumn{4}{|l|}{ C57BL/6 mice } \\
\hline \multirow[t]{5}{*}{ Spike } & S436-443 & $\mathrm{H} 2^{\mathrm{b}}$ & [64] \\
\hline & S525-532 & $\mathrm{H} 2^{\mathrm{b}}$ & [64] \\
\hline & S497-504 & $\mathrm{H} 2^{\mathrm{b}}$ & {$[75]$} \\
\hline & S627-642 & $\mathrm{H} 2^{\mathrm{b}}$ & [75] \\
\hline & S641-658 & $\mathrm{H} 2^{\mathrm{b}}$ & [75] \\
\hline Nucleocapsid & NP219-228 & $\mathrm{H} 2^{\mathrm{b}}$ & [75] \\
\hline M protein & M137-180 & $\mathrm{H} 2^{\mathrm{b}}$ & [75] \\
\hline \multicolumn{4}{|l|}{ BALB/C mice } \\
\hline \multirow[t]{3}{*}{ Spike } & S366-374 & $\mathrm{H} 2^{\mathrm{d}}$ & [64] \\
\hline & S521-529 & $\mathrm{H} 2^{\mathrm{d}}$ & [75] \\
\hline & S1031-1047 & $\mathrm{H} 2^{\mathrm{d}}$ & [110] \\
\hline \multirow[t]{3}{*}{ Nucleocapsid } & NP80-99 & $\mathrm{H} 2^{\mathrm{d}}$ & [111] \\
\hline & NP84-101 & $\mathrm{H} 2^{\mathrm{d}}$ & [111] \\
\hline & NP92-101 & $\mathrm{H} 2^{\mathrm{d}}$ & [111] \\
\hline \multicolumn{4}{|c|}{ CD4 T cell epitopes } \\
\hline \multicolumn{4}{|l|}{ C57BL/6 mice } \\
\hline \multirow[t]{4}{*}{ Nucleocapsid } & NP11-25 & $\mathrm{H} 2^{\mathrm{b}}$ & [75] \\
\hline & NP51-65 & $\mathrm{H} 2^{\mathrm{b}}$ & {$[75]$} \\
\hline & NP61-75 & $\mathrm{H} 2^{\mathrm{b}}$ & {$[75]$} \\
\hline & NP111-125 & $\mathrm{H} 2^{\mathrm{b}}$ & [75] \\
\hline \multicolumn{4}{|l|}{ BALB/C mice } \\
\hline \multirow[t]{2}{*}{ Spike } & S365-374 & $\mathrm{H} 2^{\mathrm{d}}$ & [110] \\
\hline & S435-443 & $\mathrm{H} 2^{\mathrm{d}}$ & [110] \\
\hline \multirow[t]{3}{*}{ Nucleocapsid } & NP80-99 & $\mathrm{H} 2^{\mathrm{d}}$ & [111] \\
\hline & NP353-370 & $\mathrm{H} 2^{\mathrm{d}}$ & [111] \\
\hline & NP241-258 & $\mathrm{IA}^{\mathrm{d}}$ & [111] \\
\hline
\end{tabular}

identified as a functional MERS-CoV receptor in humans [65], but mouse DPP4 (mDPP4) is not a functional receptor [66]. As a result, mice are impervious to MERS-CoV infection. Recently, Zhao et al. [67] showed that BALB/c and $\mathrm{C} 57 \mathrm{BL} / 6$ mice were sensitized for MERS-CoV infection by transduction with an adenovirus-5 (Ad5) expressing hDPP4. Following MERS-CoV infection, several $\mathrm{H} 2^{\mathrm{b}}$ restricted CD8 $\mathrm{T}$ cell epitopes were detected in the $\mathrm{S}$ (S395, S434 and S1165) and M (M64 and M165) proteins in C57BL/6 mice, and $\mathrm{H} 2{ }^{\mathrm{d}}$-restricted CD8 $\mathrm{T}$ cell epitopes were localized to the (S291, S319, S448 and S647), N (N57, N101 and N214) and M (M110 and M159) proteins in BALB/C mice.

Infection with the murine coronavirus, MHV-1, induces a severe lung pathology in $\mathrm{A} / \mathrm{J}$ and $\mathrm{C} 3 \mathrm{H} / \mathrm{HeJ}$ mice. [68, 69]. Following MHV-1 infection, virus-specific CD4 and CD8 $\mathrm{T}$ cells were identified both in susceptible $(\mathrm{C} 3 \mathrm{H} / \mathrm{HeJ})$ and in resistant (C56BL/6) strains of mice. Using direct ex vivo 
stimulation of splenocytes from infected mice with several individual overlapping peptides, IFN- $\gamma$ production was detected by flow cytometry. In C57BL/6 mice, the immunodominant, $\mathrm{IA}^{\mathrm{b}}$-restricted $\mathrm{CD} 4 \mathrm{~T}$ cell epitopes were localized to the S (S361-S375, S766-780) and M (M131$\mathrm{M} 145)$ proteins, while $\mathrm{H} 2^{\mathrm{b}}$-restricted CD8 $\mathrm{T}$ cell epitopes were found in the S (S324-317, S532-539 and S587-594) and M (M184-191) proteins. Similarly, in C3H/HeJ mice, CD4 $\mathrm{T}$ cell epitopes (I-E $\mathrm{E}^{\mathrm{k}}$ restricted) were found in the $\mathrm{S}$ (S171-S185, S921-S935 and S881-S895), N (N376-390 and N346-N360) and M (M196-210) proteins, while the only dominant CD8 $\mathrm{T}$ cell epitope was in the $\mathrm{N}$ (N421N428) protein [70].

\section{Primary $T$ cell response to respiratory coronaviruses in mice}

Virus clearance during a primary response to virus infections such as influenza and para-influenza clearly depends on virus-specific CD4 and CD8 T cells and the rapidity of virus clearance correlates with the magnitude of CD4 and CD8 T cell response [71-74]. Although several SARSCoV-specific CD4 and CD8 T cells have been detected in both infected/recovered patients and mice, very few studies have addressed the role of virus-specific $\mathrm{T}$ cells in SARS$\mathrm{CoV}$ pathogenesis. In a study using BALB/C mice, Chen et al. [26] showed that intranasal inoculation of 12-14 month-old BALB/C mice with SARS-CoV (Urbani strain) induced interstitial pneumonitis and diffuse alveolar damage. In this study, depletion of CD4 T cells (but not CD8 T cells) delayed virus clearance and further enhanced immune-mediated interstitial pneumonitis. Depletion of CD4 $\mathrm{T}$ cell also resulted in reduced neutralizing antibody titers in the lungs of SARS-CoV (Urbani)-infected mice. Since the Urbani strain of SARS-CoV induces a nonlethal, self-limiting disease, the protective role of virus-specific CD4 and CD8 T cells could not be described in this study. On the other hand, infection of young BALB/c mice with the mouse-adapted strain of SARS-CoV (SARS-CoVMA15) induces a severe disease, but generates a poor virus-specific CD4 and CD8 T cell response. Such a poor virus-specific CD4 and CD8 $\mathrm{T}$ cell response is attributed to an inefficient immune activation by SARS-CoV-MA15, particularly of respiratory DC (rDCs), as shown by reduced expression of MHC-II, CD86 and CD40 on cells harvested from the lungs. Activation of rDCs by the reversal of inhibitory mechanisms (such as depleting inhibitory alveolar macrophages or treating mice with poly $\mathrm{I}: \mathrm{C}$ ) resulted in greater numbers of anti-virus CD4 and CD8 T cells in the lungs, which ultimately correlated with better protection [49]. Subsequently, the direct evidence for the role of virus-specific CD4 and CD8 T cells in SARS-CoV clearance and host protection came from adoptive transfer studies. In one study, Zhao et al. adoptively transferred SARS-CoV-specific effector CD4 and CD8 T cells (separately) into immunodeficient SCID and RAG-/- mice or susceptible young BALB/C mice. Transfer of SARS-CoVspecific CD4 and CD8 T cells into these mice resulted in rapid virus clearance and amelioration of the clinical disease. Increasing the number of virus-specific CD8 T cells in vivo by immunization with S366-peptide-pulsed DCs also resulted in a robust $\mathrm{T}$ cell response, accelerated virus clearance and increased survival in SARS-CoV-MA-15 challenged BALB/C mice [75]. Although the adoptive transfer of SARS-CoV-specific effector CD4 and CD8 T cells controlled SARS-CoV in the lungs, it is still not known whether natural, in vivo generated virus-specific CD4 and CD8 T cells would be equally protective.

With advancing age, both humans and animals become highly susceptible to SARS-CoV and other respiratory virus infections. Such an age-dependent increase in the susceptibility is associated with a significant reduction in the magnitude of virus-specific $\mathrm{T}$ cell response $[12,27,76$, 77]. Young (6 wk) C57BL/6 mice generate a SARS-CoVspecific CD8 $\mathrm{T}$ cell response that is approximately eightfold greater than that observed in 12-month-old mice [25]. The reduction in the numbers of SARS-CoV-specific CD8 $\mathrm{T}$ cells in the lungs of aged mice is attributed in part to the impaired ability of rDCs to migrate to DLN and to prime sufficient numbers of antigen-specific CD8 T cells. Even though impaired migration of rDCs to DLN is an agedependent phenomenon, it is much pronounced in aged mice infected with SARS-CoV as compared to those infected with other respiratory viruses such as influenza A virus or respiratory syncytial virus (RSV) [27]. Migration of rDCs to DLN requires CCR7 expression [78] and CCR7 expression on rDCs is inhibited by the prostaglandin, PGD2 [79], which in turn increases in the lungs as mice age and is even further increased, however, after SARS-CoV infection [27]. Local pharmacologic inhibition of the PGD2 receptor, DP-1, with a specific antagonist (BW A868C) resulted in enhanced migration of $\mathrm{rDCs}$ to $\mathrm{DLN}$ and a subsequent augmented SARS-CoV-specific CD8 T cell response in the lungs, associated with enhanced survival of aged mice [27]. It is important to note, however, that only a partial protection (as demonstrated by $\sim 65 \%$ survival) was observed in the DP-1 antagonist (BW A868C)-treated SARS-CoV-infected aged mice. These results suggest that other age-associated factors that impair one or more components of innate or adaptive arm of the immune system also likely contribute to the deficit observed.

Similar to SARS-CoV-specific T cells, MERS-CoVspecific CD8 $\mathrm{T}$ cells also play an important role in clearing MERS-CoV in both $\mathrm{BALB} / \mathrm{c}$ and $\mathrm{C} 57 \mathrm{BL} / 6$ mice. In a recent study, infection of Ad5-hDPP4-transduced, $\mathrm{T}$ cell (TCRa-/-)-deficient mice with MERS-CoV resulted in the 
persistence of MERS-CoV in the lungs, while virus was cleared in control mice. Following MERS-CoV infection, the numbers of virus-specific CD8 T cells peaked on day 7 post-infection in the lungs of Ad5-hDPP4-transduced MERS-CoV-infected WT C57BL/6 and BALB/C mice. Additionally, effector CD8 T cells specific for immunedominant epitopes (S1165 in C57BL/6 mice and S291 in BALB/C mice) efficiently killed peptide-pulsed target cells in vivo [67]. Although Ad5-hDPP4 transduction and subsequent MERS-CoV sensitization has its limitations, this study clearly demonstrates the importance of virus-specific CD8 $\mathrm{T}$ cells in clearing MERS-CoV.

As described earlier, MHV-1 infection of the respiratory tract induces pulmonary pathology in susceptible $\mathrm{A} / \mathrm{J}$ and $\mathrm{C} 3 \mathrm{H} / \mathrm{HeJ}$ mice [70]. Unlike SARS-CoV-specific CD4 and CD8 T cells, in vivo depletion of MHV-1-specific CD4 and CD8 $\mathrm{T}$ cells in susceptible $\mathrm{A} / \mathrm{J}$ and $\mathrm{C} 3 \mathrm{H} / \mathrm{HeJ}$ mice during primary infection significantly ameliorated disease severity and improved airway function, suggesting that MHV-1specific $\mathrm{T}$ cells induce overt lung pathology in $\mathrm{A} / \mathrm{J}$ and $\mathrm{C} 3 \mathrm{H} / \mathrm{HeJ}$ mice. Thus, unlike SARS-CoV-infected mice, the $\mathrm{T}$ cell response is apparently excessive in $\mathrm{MHV}-1$-infected mice. In contrast, infection of C57BL/6 RAG1-/- mice with MHV-1 leads to significant weight loss and persistence of MHV-1 in the lungs, liver, spleen and brain during the later stages of infection (day 10 post-infection). Intranasal infection with $\mathrm{MHV}-1$ in susceptible $\mathrm{C} 3 \mathrm{H} / \mathrm{HeJ}$ mice generated robust and broad virus-specific CD4 T cell response, whereas in resistant C57BL/6 mice, antigen-specific CD8 T cell response dominated. The resistance displayed by C57BL/6 mice was probably not entirely due to greater virus-specific CD8 $\mathrm{T}$ cells, as equally robust $\mathrm{MHV}-1$-specific CD8 T cell responses in C3.SW-H2(b)/SnJ mice, was associated with significant morbidity [68]. These results are consistent with those obtained from infecting mice with the neurotropic JHM strain of MHV. MHV-JHM infection induces encephalomyelitis with both acute and chronic demyelination in mice $[80,81]$. Virus-specific CD8 T cells play a critical role in viral clearance and CD4 $\mathrm{T}$ cells provide necessary help for antiviral function of CD8 T cells [82]. Interestingly, MHV-JHM-specific CD8 T cells require distinct effector mechanisms to control virus replication in different cell types in the CNS. For instance, perforin-mediated cytolysis is crucial to control virus replication in microglia/macrophages, while virus clearance from oligodendrocytes requires IFN- $\gamma$ dependent effector functions [83]. Adoptive transfer of antigen-specific CD4 and CD8 $\mathrm{T}$ cells into infected mice lacking $\mathrm{T}$ or $\mathrm{B}$ cells (RAGI-/-) induces CNS demyelination, showing that the T cell response is required for both virus clearance and immunopathology. As in MHV-1-infected mice, $\mathrm{T}$ cells thus contribute to morbidity [84]. Studies from another coronavirus, MHV-3, which induces hepatic necrosis in mice, showed that an effective $\mathrm{T}$ cell response ameliorates disease and the Th1/Th2 balance determines resistance and susceptibility in $\mathrm{A} / \mathrm{J}$ and BALB/C mice, respectively [85].

These results suggest that the role of virus-specific primary CD4 and CD8 T cell responses to respiratory or other coronavirus infections are both virus and mouse strain dependent. Furthermore, it will be interesting to know whether MHV-1-mediated lung pathology in $\mathrm{A} / \mathrm{J}$ and $\mathrm{C} 3 \mathrm{H} /$ HeJ mice is due to an imbalance of Th1, Th2 and/or Th17 cell responses as shown in other respiratory virus infections such as RSV [85-87].

In an unrelated coronavirus infection, IBV infection is one of the leading causes of respiratory illness in young chicks. Infection of young chicks with the Gray strain of IBV induces $\mathrm{S}$ - and $\mathrm{N}$ protein-specific CD8 $\mathrm{T}$ cell responses. Adoptive transfer of virus-specific effector CD8 $\mathrm{T}$ cells (isolated from the spleen at 10-days post-infection) into a naïve chicks greatly reduced clinical illness and rapidly cleared virus from the lungs in comparison with those receiving naïve CD8 $\mathrm{T}$ cells [88]. These results show that coronavirus-specific CD8 $\mathrm{T}$ cells are also protective in this setting.

\section{The memory $\mathbf{T}$ cell response to respiratory coronaviruses}

The effector phase of an immune response is followed by a sharp contraction in the number of antigen-specific $\mathrm{T}$ cells, with 90-95\% of virus-specific $\mathrm{T}$ cells undergoing apoptosis [89]. The contraction phase is followed by a memory phase in which a stable pool of memory $T$ cells is maintained for a prolonged period of time. Such memory T cells are programmed to counter subsequent infection with the same or related pathogen, mounting rapid responses on reexposure to the pathogen in question, with minimal requirement for co-stimulatory signals [34]. It is well established now that memory $\mathrm{T}$ cells are unique in their anatomic distribution, function, maintenance and response to recall [34, 90-92]. Recent advances highlight the key role of virus-specific tissue-resident memory cells in effectively countering a local pathogen challenge. These tissue-resident memory $\mathrm{T}$ cells are well equipped to generate a rapid recall response as they are located at the site of infection and possess potent lytic activity and granzyme $\mathrm{B}$ expression [93]. The tissue-resident memory $\mathrm{T}$ cells secrete cytokines (IFN- $\gamma$ ) and chemokines (CXCL9-11) that activate innate cells and attract more memory $\mathrm{T}$ cells from the periphery $[91,92]$. Following a respiratory tract infection, memory $\mathrm{T}$ cells reside both in the lung airways and in lung interstitial tissue. The lung airways contain a high proportion of antigen-specific $\mathrm{T}$ cells in comparison with those in the lung interstitial tissue. Conversely, 
lung-airway-resident memory $\mathrm{T}$ cells lack constitutive cytolytic activity and do not proliferate in situ [94]. However, these cells are constantly replenished from the circulation, and recruitment of these cells from circulation depends on CXCR3 expression [95].

\section{Virus-specific memory $\mathrm{T}$ cell responses in humans}

Although difficult to address in humans, recent studies highlight the importance of virus-specific T memory cells in patients with respiratory disease. Thus, Sridhar et al. [96] showed that the presence of memory $\mathrm{T}$ cells correlated with protection during the recent epidemic caused by the H1N1 strain of influenza A virus. However, most of our understanding of virus-specific memory $\mathrm{T}$ cells in the lungs is derived from experimental studies using either influenza or Sendai virus in mice. In terms of patients with SARS, several studies have identified virusspecific memory CD4 and CD8 T cells in patients who recovered from the infection as long as four years after acute infection. In one such study, CD8 T cells specific for HLA-A*02:01restricted epitopes in the spike protein (SSp-1, S978 and S1202) were identified in surviving patients over one year post-infection. These virus-specific CD8 $\mathrm{T}$ cells produced high levels of effector cytokines (IFN- $\gamma$ and TNF- $\alpha$ ) and cytotoxic molecules (perforin and granzyme B) after peptide stimulation in vitro [97]. Memory CD4 T cells specific for HLA-DR08- and HLADR15-restricted epitopes within the S protein of SARS-CoV were also identified in recovered individuals [58]. Using pools of overlapping peptides, $\mathrm{N}, \mathrm{M}$ and $\mathrm{E}$ protein-specific CD4 and CD8 T cells were identified in PBMCs from SARS-recovered individuals at 2-years post-infection. Virus-specific CD4 $\mathrm{T}$ cells mainly exhibited a central memory phenotype (CD45RA ${ }^{-} \mathrm{CCR} 7^{+} \mathrm{CD}^{2} \mathrm{~L}^{-}$), whereas $\mathrm{CD} 8$ memory $\mathrm{T}$ cells were effector memory cells $\left(\mathrm{CD} 45 \mathrm{RA}^{+} \mathrm{CCR} 7^{-} \mathrm{CD}^{2} \mathrm{~L}^{-}\right)[53$, $55,98,99]$. In a phase I clinical trial, vaccination of healthy individuals with rDNA encoding spike (S) protein of SARS$\mathrm{CoV}$ elicited both neutralizing antibodies and the spike-proteinspecific $\mathrm{T}$ cell responses. The majority of SARS-CoV spikeprotein-specific $\mathrm{T}$ cells were CD4 T cells (10/10 subjects), and a minority of subjects had detectable spike protein-specific CD8+ $\mathrm{T}$ cell responses (2/10 subjects) [100]. Collectively, these studies suggest a potential role for virus-specific memory $\mathrm{T}$ cells in broad and long-term protection against SARS-CoV infection. This is important as neutralizing Abs and the memory B cells response to SARS-CoV decline significantly after 1-2 years post-infection and are also strain specific.

Virus-specific memory $\mathrm{T}$ cell response in animals

Similar to the human studies, analysis of experimental animals has demonstrated the presence of SARS-CoVspecific CD4 and CD8 T cells following rDNA vaccination or recombinant virus immunizations. Intramuscular immunization of rhesus macaques with recombinant adenovirus (rAd5) encoding the SARS-CoV-N protein, followed by a booster vaccination on day 28 induced $\mathrm{N}$-specific-T cell responses [101]. Immunization of mice with $\mathrm{rDNA}$ vaccine encoding the $\mathrm{S}, \mathrm{N}, \mathrm{M}$ or $\mathrm{E}$ protein of SARS-CoV induced virus-specific memory CD4 and CD8 $\mathrm{T}$ cells $[63,102,103]$. Virus-specific memory CD4 and CD8 T cells were able to produce effector cytokines (e.g., IFN- $\gamma$ ) and cytolytic molecules upon in vitro peptide stimulation [102]. Although several groups demonstrated the presence of SARS-CoV-specific memory CD4 and CD8 $\mathrm{T}$ cells, very few studies have demonstrated their in vivo potential to clear virus. In one study, depletion of virus-specific memory CD4 and CD8 T cells in BALB/C mice immunized with rDNA (encoding $\mathrm{S}$ protein) did not have any effect on virus clearance on day 2 post-challenge [60]. However, caveats of this study were that the Urbani strain, which is largely non-pathogenic in mice, was used and that the authors did not examine the effect of CD4 and CD8 $\mathrm{T}$ cell depletion on virus clearance during later time points, when virus-specific effector memory CD4 and CD8 $\mathrm{T}$ cells would be expected to exert their antiviral functions. In another study, Ohno et al. [104] identified HLAA*0201-restricted SARS-CoV-N-specific CTLs in infected HLA-A*0201 transgenic mice, using surface-linked liposomal peptides a CTL-based vaccine against SARS-CoV infection. These surface-linked liposomal peptides (derived from the $\mathrm{N}$ protein) effectively induced CTL responses, and upon challenge, these immunized mice rapidly cleared vaccinia virus (VV) expressing the SARS-CoV-N. In an unpublished study, we demonstrated the protective role for SARS-CoV-S-specific memory CD8 $\mathrm{T}$ cells following lethal SARS-CoV infection in 9- to 11-month-old C57BL/6 mice. In this study, intravenous DC-peptide (DC-S436/ S525) immunization followed by intranasal boosting with recombinant vaccinia virus encoding S436/S525 generated large pool of S436/S525-specific memory CD8 T cells in the lungs of 9- to 11-month-old C57B1/6 mice. The virusspecific memory CD8 $\mathrm{T}$ cells in the lungs provided partial but significant protection against lethal SARS-CoV challenge. These data suggest that virus-specific memory CD8 $\mathrm{T}$ cells enhance the kinetics of virus clearance and protect the susceptible host from lethal SARS-CoV infection. However, the protection was not as effective as observed after the natural infection, suggesting a role for anti-virus CD4 $\mathrm{T}$ cells or anti-virus antibodies in providing optimal protection.

In contrast, adoptive transfer of MHV-1-specific memory CD4 and CD8 $\mathrm{T}$ cells (bulk memory splenocytes or purified memory CD4 and CD8 $\mathrm{T}$ cells isolated from spleen) enhanced morbidity and mortality in MHV-1challenged $\mathrm{C} 3 \mathrm{H} / \mathrm{HeJ}$ mice [68]. The lung pathology in these mice was possibly not due to robust IFN- $\gamma$ and other 
pro-inflammatory cytokines production as even a sub-lethal dose of MHV-1 infection generates greater magnitude of virus-specific $\mathrm{CD} 4$ and $\mathrm{CD} 8 \mathrm{~T}$ cell response. Another possibility is that in the absence of immune serum or a $B$ cell response, virus-specific memory $\mathrm{T}$ cells cannot provide complete protection [105]. In mice infected with neurotropic MHV-JHM strain, antigen-specific memory CD8 T cells were generated after immunization with rVV expressing the immunodominant CD8 T cell epitope (pN9). Following CNS MHV-JHM challenge, pN9-specific CD8 T cells exhibited rapid recall in the lymphoid organs were rapidly recruited to the CNS in increased numbers and facilitated efficient MHV-JHM clearance from the CNS [106]. Memory virus-specific CD4 T cells are also protective in these infections [107].

In IBV infected chicks, adoptive transfer of memory CD8 $\mathrm{T}$ cells (isolated from the spleen at 3-6 weeks post IBV infection) but not CD4 protected young chicks from lethal IBV infection. In these studies, memory CD8 T cells showed cytolytic activity in in vitro assays and completely cleared the IBV from lungs and kidneys [108, 109].

Although there is a limited amount of data available on virus-specific memory $\mathrm{T}$ cell responses to emerging coronaviruses, the existing studies indicate that lung resident virus-specific memory CD8 $\mathrm{T}$ cells provide substantial protection following SARS-CoV challenge.

\section{Summary and conclusion}

In this review, we discussed our current understanding of the virus-specific $\mathrm{T}$ cell-mediated immune response to respiratory coronaviruses. Several lines of evidence from other respiratory virus infections such as influenza $A$ and para-influenza have established that virus-specific CD4 and CD8 $\mathrm{T}$ cells generated during primary and memory response are able clear virus and protect the host from lethal infections. On the contrary, virus-specific $\mathrm{T}$ cell response to respiratory coronaviruses and their ability to clear virus depends on the type of pathogen in question and the host used in the study. In case of mice infected with SARS-CoV, virus-specific CD8 $\mathrm{T}$ cells in the absence of antibody or $\mathrm{CD} 4 \mathrm{~T}$ cells responding to virus provide a partial but significant level of protection and effect virus clearance. On the other hand, MHV-1-specific T cells are detrimental and induce lung pathology in susceptible $\mathrm{A} / \mathrm{J}$ and $\mathrm{C} 3 \mathrm{H} / \mathrm{HeJ}$ mice.

Follow-up studies from patients who recovered from SARS suggest that the SARS-CoV-specific antibody response is short lived. In these patients, SARS-CoV-specific $\operatorname{IgM}$ and $\operatorname{IgA}$ response lasted less than 6 months, while virus-specific IgG titer peaked four-month postinfection and markedly declined after 1 year. Despite the lack of virus-specific memory B cell response, SARS-CoVspecific memory $\mathrm{T}$ cells persist in SARS-recovered patients for up to 6 years post-infection. Consistent with these human studies, results from animal studies also suggest that strong virus-specific $\mathrm{T}$ cell response are required to protect mice from lethal SARS-CoV-MA15 infection. The future vaccine interventions should also consider strategies to enhance $\mathrm{T}$ cell response to provide robust long-term memory. Since, tissue-resident memory $\mathrm{T}$ cells provide better protection, boosting a local and systemic memory $\mathrm{T}$ cell response would be a useful strategy than either of these interventions alone.

\section{References}

1. Siddell S, Ziebuhr J, Snijder EJ. Coronaviruses, toroviruses, and arteriviruses, vol. 1. London: Hodder Arnold; 2005. p. 823-56.

2. Weiss SR, Navas-Martin S. Coronavirus pathogenesis and the emerging pathogen severe acute respiratory syndrome coronavirus. Microbiol Mol Biol Rev. 2005;69:635-64.

3. Heugel J, Martin ET, Kuypers J, Englund JA. Coronavirusassociated pneumonia in previously healthy children. Pediatr Infect Dis J. 2007;26:753-5.

4. Kuypers J, Martin ET, Heugel J, Wright N, Morrow R, Englund JA. Clinical disease in children associated with newly described coronavirus subtypes. Pediatrics. 2007;119:e70-6.

5. Rota PA, Oberste MS, Monroe SS, Nix WA, Campagnoli R, Icenogle JP, Penaranda S, Bankamp B, Maher K, Chen MH, Tong S, Tamin A, Lowe L, Frace M, DeRisi JL, Chen Q, Wang D, Erdman DD, Peret TC, Burns C, Ksiazek TG, Rollin PE, Sanchez A, Liffick S, Holloway B, Limor J, McCaustland K, Olsen-Rasmussen M, Fouchier R, Gunther S, Osterhaus AD, Drosten C, Pallansch MA, Anderson LJ, Bellini WJ. Characterization of a novel coronavirus associated with severe acute respiratory syndrome. Science. 2003;300:1394-9.

6. Marra MA, Jones SJ, Astell CR, Holt RA, Brooks-Wilson A, Butterfield YS, Khattra J, Asano JK, Barber SA, Chan SY, Cloutier A, Coughlin SM, Freeman D, Girn N, Griffith OL, Leach SR, Mayo M, McDonald H, Montgomery SB, Pandoh PK, Petrescu AS, Robertson AG, Schein JE, Siddiqui A, Smailus DE, Stott JM, Yang GS, Plummer F, Andonov A, Artsob H, Bastien N, Bernard K, Booth TF, Bowness D, Czub M, Drebot M, Fernando L, Flick R, Garbutt M, Gray M, Grolla A, Jones S, Feldmann H, Meyers A, Kabani A, Li Y, Normand S, Stroher U, Tipples GA, Tyler S, Vogrig R, Ward D, Watson B, Brunham RC, Krajden M, Petric M, Skowronski DM, Upton C, Roper RL. The genome sequence of the SARS-associated coronavirus. Science. 2003;300:1399-404.

7. Kuiken T, Fouchier RA, Schutten M, Rimmelzwaan GF, van Amerongen G, van Riel D, Laman JD, de Jong T, van Doornum G, Lim W, Ling AE, Chan PK, Tam JS, Zambon MC, Gopal R, Drosten C, van der Werf S, Escriou N, Manuguerra JC, Stohr K, Peiris JS, Osterhaus AD. Newly discovered coronavirus as the primary cause of severe acute respiratory syndrome. Lancet. 2003;362:263-70.

8. Zaki AM, van Boheemen S, Bestebroer TM, Osterhaus AD, Fouchier RA. Isolation of a novel coronavirus from a man with pneumonia in Saudi Arabia. N Engl J Med. 2012;367:1814-20.

9. van Boheemen S, de Graaf M, Lauber C, Bestebroer TM, Raj VS, Zaki AM, Osterhaus AD, Haagmans BL, Gorbalenya AE, 
Snijder EJ, Fouchier RA. Genomic characterization of a newly discovered coronavirus associated with acute respiratory distress syndrome in humans. mBio. 2012;3(6):e00473-12.

10. Perlman S, Dandekar AA. Immunopathogenesis of coronavirus infections: implications for SARS. Nat Rev Immunol. 2005;5: 917-27.

11. Perlman S, Netland J. Coronaviruses post-SARS: update on replication and pathogenesis. Nat Rev Microbiol. 2009;7: 439-50.

12. Peiris JS, Guan Y, Yuen KY. Severe acute respiratory syndrome. Nat Med. 2004;10:S88-97.

13. Alexander DJ, Gough RE. A long-term study of the pathogenesis of infection of fowls with three strains of avian infectious bronchitis virus. Res Vet Sci. 1978;24:228-33.

14. van der Hoek L, Sure K, Ihorst G, Stang A, Pyrc K, Jebbink MF, Petersen G, Forster J, Berkhout B, Uberla K. Croup is associated with the novel coronavirus NL63. PLoS Med. 2005;2:e240.

15. World Health Organization. Middle East respiratory syndrome coronavirus (MERS-CoV)—update. 2014. http://www.who.int/ csr/don/2014_03_25/en/.

16. Lew TW, Kwek TK, Tai D, Earnest A, Loo S, Singh K, Kwan KM, Chan Y, Yim CF, Bek SL, Kor AC, Yap WS, Chelliah YR, Lai YC, Goh SK. Acute respiratory distress syndrome in critically ill patients with severe acute respiratory syndrome. J Am Med Assoc. 2003;290:374-80.

17. Kong SL, Chui P, Lim B, Salto-Tellez M. Elucidating the molecular physiopathology of acute respiratory distress syndrome in severe acute respiratory syndrome patients. Virus Res. 2009;145:260-9.

18. Wong CK, Lam CW, Wu AK, Ip WK, Lee NL, Chan IH, Lit LC, Hui DS, Chan MH, Chung SS, Sung JJ. Plasma inflammatory cytokines and chemokines in severe acute respiratory syndrome. Clin Exp Immunol. 2004;136:95-103.

19. Baas T, Taubenberger JK, Chong PY, Chui P, Katze MG. SARS-CoV virus-host interactions and comparative etiologies of acute respiratory distress syndrome as determined by transcriptional and cytokine profiling of formalin-fixed paraffinembedded tissues. J Interferon Cytokine Res Off J Int Soc Interferon Cytokine Res. 2006;26:309-17.

20. Subbarao K, Roberts A. Is there an ideal animal model for SARS? Trends Microbiol. 2006;14:299-303.

21. van den Brand JM, Haagmans BL, van Riel D, Osterhaus AD, Kuiken T. The pathology and pathogenesis of experimental severe acute respiratory syndrome and influenza in animal models. J Comp Pathol. 2014. doi:10.1016/j.jcpa.2014. 01.004 .

22. Martina BE, Haagmans BL, Kuiken T, Fouchier RA, Rimmelzwaan GF, Van Amerongen G, Peiris JS, Lim W, Osterhaus AD. Virology: SARS virus infection of cats and ferrets. Nature. 2003;425:915.

23. Roberts A, Paddock C, Vogel L, Butler E, Zaki S, Subbarao K. Aged BALB/c mice as a model for increased severity of severe acute respiratory syndrome in elderly humans. J Virol. 2005;79:5833-8.

24. Fouchier RA, Kuiken T, Schutten M, van Amerongen G, van Doornum GJ, van den Hoogen BG, Peiris M, Lim W, Stohr K, Osterhaus AD. Aetiology: Koch's postulates fulfilled for SARS virus. Nature. 2003;423:240.

25. Roberts A, Deming D, Paddock CD, Cheng A, Yount B, Vogel L, Herman BD, Sheahan T, Heise M, Genrich GL, Zaki SR, Baric R, Subbarao K. A mouse-adapted SARS-coronavirus causes disease and mortality in BALB/c mice. PLoS Pathog. 2007;3:e5.

26. Chen J, Lau YF, Lamirande EW, Paddock CD, Bartlett JH, Zaki SR, Subbarao K. Cellular immune responses to severe acute respiratory syndrome coronavirus (SARS-CoV) infection in senescent BALB/c mice: CD4+ T cells are important in control of SARS-CoV infection. J Virol. 2010;84:1289-301.

27. Zhao J, Zhao J, Legge K, Perlman S. Age-related increases in $\mathrm{PGD}(2)$ expression impair respiratory DC migration, resulting in diminished $\mathrm{T}$ cell responses upon respiratory virus infection in mice. J Clin Investig. 2011;121:4921-30.

28. Kim KD, Zhao J, Auh S, Yang X, Du P, Tang H, Fu YX. Adaptive immune cells temper initial innate responses. Nat Med. 2007;13:1248-52.

29. Palm NW, Medzhitov R. Not so fast: adaptive suppression of innate immunity. Nat Med. 2007;13:1142-4.

30. Bouvier NM, Lowen AC. Animal models for influenza virus pathogenesis and transmission. Viruses. 2010;2:1530-63.

31. Belz GT, Smith CM, Kleinert L, Reading P, Brooks A, Shortman K, Carbone FR, Heath WR. Distinct migrating and nonmigrating dendritic cell populations are involved in MHC class I-restricted antigen presentation after lung infection with virus. Proc Natl Acad Sci USA. 2004;101:8670-5.

32. Larsson M, Messmer D, Somersan S, Fonteneau JF, Donahoe SM, Lee M, Dunbar PR, Cerundolo V, Julkunen I, Nixon DF, Bhardwaj N. Requirement of mature dendritic cells for efficient activation of influenza A-specific memory CD8+ $\mathrm{T}$ cells. J Immunol. 2000;165:1182-90.

33. Norbury CC, Malide D, Gibbs JS, Bennink JR, Yewdell JW. Visualizing priming of virus-specific CD8 $+\mathrm{T}$ cells by infected dendritic cells in vivo. Nat Immunol. 2002;3:265-71.

34. Wherry EJ, Ahmed R. Memory CD8 T-cell differentiation during viral infection. J Virol. 2004;78:5535-45.

35. Saha B, Jyothi Prasanna S, Chandrasekar B, Nandi D. Gene modulation and immunoregulatory roles of interferon gamma. Cytokine. 2010;50:1-14.

36. Roman E, Miller E, Harmsen A, Wiley J, Von Andrian UH, Huston G, Swain SL. CD4 effector T cell subsets in the response to influenza: heterogeneity, migration, and function. J Exp Med. 2002;196:957-68.

37. Swain SL, Agrewala JN, Brown DM, Roman E. Regulation of memory CD4 T cells: generation, localization and persistence. Adv Exp Med Biol. 2002;512:113-20.

38. Cerwenka A, Morgan TM, Dutton RW. Naive, effector, and memory $\mathrm{CD} 8 \mathrm{~T}$ cells in protection against pulmonary influenza virus infection: homing properties rather than initial frequencies are crucial. J Immunol. 1999;163:5535-43.

39. Cerwenka A, Morgan TM, Harmsen AG, Dutton RW. Migration kinetics and final destination of type 1 and type 2 CD8 effector cells predict protection against pulmonary virus infection. J Exp Med. 1999;189:423-34.

40. Wong RS, Wu A, To KF, Lee N, Lam CW, Wong CK, Chan PK, Ng MH, Yu LM, Hui DS, Tam JS, Cheng G, Sung JJ. Haematological manifestations in patients with severe acute respiratory syndrome: retrospective analysis. BMJ. 2003;326:1358-62.

41. Cui W, Fan Y, Wu W, Zhang F, Wang JY, Ni AP. Expression of lymphocytes and lymphocyte subsets in patients with severe acute respiratory syndrome. Clin Infect Dis Off Publ Infect Dis Soc Am. 2003;37:857-9.

42. Li T, Qiu Z, Zhang L, Han Y, He W, Liu Z, Ma X, Fan H, Lu W, Xie J, Wang H, Deng G, Wang A. Significant changes of peripheral $\mathrm{T}$ lymphocyte subsets in patients with severe acute respiratory syndrome. J Infect Dis. 2004;189:648-51.

43. Cai C, Zeng X, Ou AH, Huang Y, Zhang X. [Study on T cell subsets and their activated molecules from the convalescent SARS patients during two follow-up surveys]. Xi bao yu fen zi mian yi xue za zhi $=$. Chin J Cell Mol Immunol. 2004;20:322-4.

44. Yu XY, Zhang YC, Han CW, Wang P, Xue XJ, Cong YL. [Change of $T$ lymphocyte and its activated subsets in SARS patients]. Zhongguo Yi Xue Ke Xue Yuan Xue Bao. Acta Academiae Medicinae Sinicae. 2003;25:542-6. 
45. Cameron MJ, Bermejo-Martin JF, Danesh A, Muller MP, Kelvin DJ. Human immunopathogenesis of severe acute respiratory syndrome (SARS). Virus Res. 2008;133:13-9.

46. Assiri A, Al-Tawfiq JA, Al-Rabeeah AA, Al-Rabiah FA, Al-Hajjar S, Al-Barrak A, Flemban H, Al-Nassir WN, Balkhy HH, Al-Hakeem RF, Makhdoom HQ, Zumla AI, Memish ZA. Epidemiological, demographic, and clinical characteristics of 47 cases of Middle East respiratory syndrome coronavirus disease from Saudi Arabia: a descriptive study. Lancet Infect Dis. 2013;13:752-61.

47. Li T, Qiu Z, Han Y, Wang Z, Fan H, Lu W, Xie J, Ma X, Wang A. Rapid loss of both CD4+ and CD8+ T lymphocyte subsets during the acute phase of severe acute respiratory syndrome. Chin Med J. 2003;116:985-7.

48. Yoshikawa T, Hill T, Li K, Peters CJ, Tseng CT. Severe acute respiratory syndrome (SARS) coronavirus-induced lung epithelial cytokines exacerbate SARS pathogenesis by modulating intrinsic functions of monocyte-derived macrophages and dendritic cells. J Virol. 2009;83:3039-48.

49. Zhao J, Zhao J, Van Rooijen N, Perlman S. Evasion by stealth: inefficient immune activation underlies poor $\mathrm{T}$ cell response and severe disease in SARS-CoV-infected mice. PLoS Pathog. 2009;5:e1000636.

50. Bahl K, Kim SK, Calcagno C, Ghersi D, Puzone R, Celada F, Selin LK, Welsh RM. IFN-induced attrition of CD8 T cells in the presence or absence of cognate antigen during the early stages of viral infections. J Immunol. 2006;176:4284-95.

51. Xu X, Gao X. Immunological responses against SARS-coronavirus infection in humans. Cell Mol Immunol. 2004;1:119-22.

52. Wang YD, Sin WY, Xu GB, Yang HH, Wong TY, Pang XW, He XY, Zhang HG, Ng JN, Cheng CS, Yu J, Meng L, Yang RF, Lai ST, Guo ZH, Xie Y, Chen WF. T-cell epitopes in severe acute respiratory syndrome (SARS) coronavirus spike protein elicit a specific T-cell immune response in patients who recover from SARS. J Virol. 2004;78:5612-8.

53. Yang LT, Peng H, Zhu ZL, Li G, Huang ZT, Zhao ZX, Koup RA, Bailer RT, Wu CY. Long-lived effector/central memory T-cell responses to severe acute respiratory syndrome coronavirus (SARS-CoV) S antigen in recovered SARS patients. Clin Immunol. 2006;120:171-8.

54. Lv Y, Ruan Z, Wang L, Ni B, Wu Y. Identification of a novel conserved HLA-A*0201-restricted epitope from the spike protein of SARS-CoV. BMC Immunol. 2009;10:61.

55. Oh H-L, Gan S, Bertoletti A, Tan Y-J. Understanding the T cell immune response in SARS coronavirus infection. Emerg Microbes Infect. 2012;1:e23-8.

56. Fan YY, Huang ZT, Li L, Wu MH, Yu T, Koup RA, Bailer RT, $\mathrm{Wu}$ CY. Characterization of SARS-CoV-specific memory $\mathrm{T}$ cells from recovered individuals 4 years after infection. Arch Virol. 2009;154:1093-9.

57. Peng H, Yang LT, Wang LY, Li J, Huang J, Lu ZQ, Koup RA, Bailer RT, Wu CY. Long-lived memory T lymphocyte responses against SARS coronavirus nucleocapsid protein in SARSrecovered patients. Virology. 2006;351:466-75.

58. Libraty DH, O'Neil KM, Baker LM, Acosta LP, Olveda RM. Human CD4(+) memory T-lymphocyte responses to SARS coronavirus infection. Virology. 2007;368:317-21.

59. Bolles M, Deming D, Long K, Agnihothram S, Whitmore A, Ferris M, Funkhouser W, Gralinski L, Totura A, Heise M, Baric RS. A double-inactivated severe acute respiratory syndrome coronavirus vaccine provides incomplete protection in mice and induces increased eosinophilic proinflammatory pulmonary response upon challenge. J Virol. 2011;85:12201-15.

60. Yang ZY, Kong WP, Huang Y, Roberts A, Murphy BR, Subbarao K, Nabel GJ. A DNA vaccine induces SARS coronavirus neutralization and protective immunity in mice. Nature. 2004;428:561-4.
61. Zhu MS, Pan Y, Chen HQ, Shen Y, Wang XC, Sun YJ, Tao KH. Induction of SARS-nucleoprotein-specific immune response by use of DNA vaccine. Immunol Lett. 2004;92:237-43.

62. Wang ZQ, Cui J, Wei HY, Han HM, Zhang HW, Li YL. Vaccination of mice with DNA vaccine induces the immune response and partial protection against $\mathrm{T}$. spiralis infection. Vaccine. 2006;24:1205-12.

63. Jin H, Xiao C, Chen Z, Kang Y, Ma Y, Zhu K, Xie Q, Tu Y, Yu $\mathrm{Y}$, Wang B. Induction of Th1 type response by DNA vaccinations with $\mathrm{N}, \mathrm{M}$, and $\mathrm{E}$ genes against SARS-CoV in mice. Biochem Biophys Res Commun. 2005;328:979-86.

64. Zhi Y, Kobinger GP, Jordan H, Suchma K, Weiss SR, Shen H, Schumer G, Gao G, Boyer JL, Crystal RG, Wilson JM. Identification of murine CD8 T cell epitopes in codon-optimized SARSassociated coronavirus spike protein. Virology. 2005;335:34-45.

65. Raj VS, Mou H, Smits SL, Dekkers DH, Muller MA, Dijkman R, Muth D, Demmers JA, Zaki A, Fouchier RA, Thiel V, Drosten C, Rottier PJ, Osterhaus AD, Bosch BJ, Haagmans BL. Dipeptidyl peptidase 4 is a functional receptor for the emerging human coronavirus-EMC. Nature. 2013;495:251-4.

66. Cockrell AS, Peck KM, Yount BL, Agnihothram SS, Scobey T, Curnes NR, Baric RS, Heise MT. Mouse dipeptidyl peptidase 4 (DPP4) is not a functional receptor for Middle East respiratory syndrome coronavirus (MERS-CoV) infection. J Virol. 2014;88: 5195-9.

67. Zhao J, Li K, Wohlford-Lenane C, Agnihothram SS, Fett C, Zhao J, Gale MJ Jr, Baric RS, Enjuanes L, Gallagher T, McCray PB Jr, Perlman S. Rapid generation of a mouse model for Middle East respiratory syndrome. In: Proceedings of the national academy of sciences of the United States of America; 2014.

68. Khanolkar A, Hartwig SM, Haag BA, Meyerholz DK, Epping LL, Haring JS, Varga SM, Harty JT. Protective and pathologic roles of the immune response to mouse hepatitis virus type 1: implications for severe acute respiratory syndrome. J Virol. 2009;83:9258-72.

69. De Albuquerque N, Baig E, Ma X, Zhang J, He W, Rowe A, Habal M, Liu M, Shalev I, Downey GP, Gorczynski R, Butany J, Leibowitz J, Weiss SR, McGilvray ID, Phillips MJ, Fish EN, Levy GA. Murine hepatitis virus strain 1 produces a clinically relevant model of severe acute respiratory syndrome in $\mathrm{A} / \mathrm{J}$ mice. J Virol. 2006;80:10382-94.

70. Khanolkar A, Fulton RB, Epping LL, Pham NL, Tifrea D, Varga SM, Harty JT. T cell epitope specificity and pathogenesis of mouse hepatitis virus-1-induced disease in susceptible and resistant hosts. J Immunol. 2010;185:1132-41.

71. Brown DM, Dilzer AM, Meents DL, Swain SL. CD4 T cellmediated protection from lethal influenza: perforin and antibody-mediated mechanisms give a one-two punch. J Immunol. 2006;177:2888-98.

72. Christensen JP, Doherty PC, Branum KC, Riberdy JM. Profound protection against respiratory challenge with a lethal H7N7 influenza A virus by increasing the magnitude of CD8(+) T-cell memory. J Virol. 2000;74:11690-6.

73. Eichelberger M, Allan W, Zijlstra M, Jaenisch R, Doherty PC. Clearance of influenza virus respiratory infection in mice lacking class I major histocompatibility complex-restricted CD8+ T cells. J Exp Med. 1991;174:875-80.

74. Zhong W, Roberts AD, Woodland DL. Antibody-independent antiviral function of memory $\mathrm{CD} 4+\mathrm{T}$ cells in vivo requires regulatory signals from $\mathrm{CD} 8+$ effector $\mathrm{T}$ cells. J Immunol. 2001;167:1379-86.

75. Zhao J, Zhao J, Perlman S. T cell responses are required for protection from clinical disease and for virus clearance in severe acute respiratory syndrome coronavirus-infected mice. J Virol. 2010;84:9318-25. 
76. Murasko DM, Jiang J. Response of aged mice to primary virus infections. Immunol Rev. 2005;205:285-96.

77. Gardner EM, Gonzalez EW, Nogusa S, Murasko DM. Age-related changes in the immune response to influenza vaccination in a racially diverse, healthy elderly population. Vaccine. 2006;24:1609-14.

78. Sanchez-Sanchez N, Riol-Blanco L, Rodriguez-Fernandez JL. The multiple personalities of the chemokine receptor CCR7 in dendritic cells. J Immunol. 2006;176:5153-9.

79. Gosset P, Pichavant M, Faveeuw C, Bureau F, Tonnel AB, Trottein F. Prostaglandin D2 affects the differentiation and functions of human dendritic cells: impact on the $\mathrm{T}$ cell response. Eur J Immunol. 2005;35:1491-500.

80. Lampert PW, Sims JK, Kniazeff AJ. Mechanism of demyelination in JHM virus encephalomyelitis. Electron microscopic studies. Acta Neuropathologica. 1973;24:76-85.

81. Knobler RL, Haspel MV, Oldstone MB. Mouse hepatitis virus type 4 (JHM strains) induced fatal central nervous system disease. I. Genetic control and murine neuron as the susceptible site of disease. J Exp Med. 1981;153:832-43.

82. Williamson JS, Stohlman SA. Effective clearance of mouse hepatitis virus from the central nervous system requires both CD4+ and CD8+ T cells. J Virol. 1990;64:4589-92.

83. Bergmann CC, Lane TE, Stohlman SA. Coronavirus infection of the central nervous system: host-virus stand-off. Nat Rev Microbiol. 2006;4:121-32.

84. Wu GF, Dandekar AA, Pewe L, Perlman S. CD4 and CD8 T cells have redundant but not identical roles in virus-induced demyelination. J Immunol. 2000;165:2278-86.

85. Pope M, Chung SW, Mosmann T, Leibowitz JL, Gorczynski RM, Levy GA. Resistance of naive mice to murine hepatitis virus strain 3 requires development of a Th1, but not a Th2, response, whereas pre-existing antibody partially protects against primary infection. J Immunol. 1996;156:3342-9.

86. Bystrom J, Al-Adhoubi N, Al-Bogami M, Jawad AS, Mageed RA. Th17 lymphocytes in respiratory syncytial virus infection. Viruses. 2013;5:777-91.

87. Graham BS, Bunton LA, Wright PF, Karzon DT. Role of T lymphocyte subsets in the pathogenesis of primary infection and rechallenge with respiratory syncytial virus in mice. J Clin Investig. 1991;88:1026-33.

88. Collisson EW, Pei J, Dzielawa J, Seo SH. Cytotoxic T lymphocytes are critical in the control of infectious bronchitis virus in poultry. Dev Comp Immunol. 2000;24:187-200.

89. Murali-Krishna K, Altman JD, Suresh M, Sourdive DJ, Zajac AJ, Miller JD, Slansky J, Ahmed R. Counting antigen-specific CD8 T cells: a reevaluation of bystander activation during viral infection. Immunity. 1998;8:177-87.

90. Bachmann MF, Barner M, Viola A, Kopf M. Distinct kinetics of cytokine production and cytolysis in effector and memory $\mathrm{T}$ cells after viral infection. Eur J Immunol. 1999;29:291-9.

91. Strutt TM, McKinstry KK, Dibble JP, Winchell C, Kuang Y, Curtis JD, Huston G, Dutton RW, Swain SL. Memory CD4+ T cells induce innate responses independently of pathogen. Nat Med. 2010. 16:558-564, 551 p following 564.

92. Schenkel JM, Fraser KA, Vezys V, Masopust D. Sensing and alarm function of resident memory $\mathrm{CD} 8(+) \mathrm{T}$ cells. Nat Immunol. 2013;14:509-13.

93. Kohlmeier JE, Woodland DL. Immunity to respiratory viruses. Annu Rev Immunol. 2009;27:61-82.

94. Woodland DL, Scott I. T cell memory in the lung airways. Proc Am Thorac Soc. 2005;2:126-31.

95. Slutter B, Pewe LL, Kaech SM, Harty JT. Lung airway-surveilling CXCR3(hi) memory CD8(+) T cells are critical for protection against influenza A virus. Immunity. 2013;39:939-48.

96. Sridhar S, Begom S, Bermingham A, Hoschler K, Adamson W, Carman W, Bean T, Barclay W, Deeks JJ, Lalvani A. Cellular immune correlates of protection against symptomatic pandemic influenza. Nat Med. 2013;19:1305-12.

97. Chen H, Hou J, Jiang X, Ma S, Meng M, Wang B, Zhang M, Zhang M, Tang X, Zhang F, Wan T, Li N, Yu Y, Hu H, Yang R, He W, Wang X, Cao X. Response of memory CD8+ T cells to severe acute respiratory syndrome (SARS) coronavirus in recovered SARS patients and healthy individuals. J Immunol. 2005;175:591-8.

98. Peng H, Yang LT, Li J, Lu ZQ, Wang LY, Koup RA, Bailer RT, $\mathrm{Wu} \mathrm{CY}$. Human memory $\mathrm{T}$ cell responses to SARS-CoV $\mathrm{E}$ protein. Microbes Infect/Institut Pasteur. 2006;8:2424-31.

99. Yang L, Peng H, Zhu Z, Li G, Huang Z, Zhao Z, Koup RA, Bailer RT, Wu C. Persistent memory CD4+ and CD8+ T-cell responses in recovered severe acute respiratory syndrome (SARS) patients to SARS coronavirus M antigen. J Gen Virol. 2007;88:2740-8.

100. Martin JE, Louder MK, Holman LA, Gordon IJ, Enama ME, Larkin BD, Andrews CA, Vogel L, Koup RA, Roederer M, Bailer RT, Gomez PL, Nason M, Mascola JR, Nabel GJ, Graham BS, Team VRCS. A SARS DNA vaccine induces neutralizing antibody and cellular immune responses in healthy adults in a Phase I clinical trial. Vaccine. 2008;26:6338-43.

101. Gao W, Tamin A, Soloff A, D'Aiuto L, Nwanegbo E, Robbins PD, Bellini WJ, Barratt-Boyes S, Gambotto A. Effects of a SARS-associated coronavirus vaccine in monkeys. Lancet. 2003;362:1895-6.

102. Zhao P, Cao J, Zhao LJ, Qin ZL, Ke JS, Pan W, Ren H, Yu JG, Qi ZT. Immune responses against SARS-coronavirus nucleocapsid protein induced by DNA vaccine. Virology. 2005;331:128-35.

103. Wang Z, Yuan Z, Matsumoto M, Hengge UR, Chang YF. Immune responses with DNA vaccines encoded different gene fragments of severe acute respiratory syndrome coronavirus in BALB/c mice. Biochem Biophys Res Commun. 2005;327:130-5.

104. Ohno S, Kohyama S, Taneichi M, Moriya O, Hayashi H, Oda H, Mori M, Kobayashi A, Akatsuka T, Uchida T, Matsui M. Synthetic peptides coupled to the surface of liposomes effectively induce SARS coronavirus-specific cytotoxic T lymphocytes and viral clearance in HLA-A*0201 transgenic mice. Vaccine. 2009;27:3912-20.

105. Xu RH, Fang M, Klein-Szanto A, Sigal LJ. Memory CD8+ T cells are gatekeepers of the lymph node draining the site of viral infection. Proc Natl Acad Sci USA. 2007;104:10992-7.

106. Ramakrishna C, Stohlman SA, Atkinson RA, Hinton DR, Bergmann CC. Differential regulation of primary and secondary $\mathrm{CD} 8+\mathrm{T}$ cells in the central nervous system. J Immunol. 2004; 173:6265-73.

107. Savarin C, Bergmann CC, Hinton DR, Ransohoff RM, Stohlman SA. Memory CD4+ T-cell-mediated protection from lethal coronavirus encephalomyelitis. J Virol. 2008;82:12432-40.

108. Pei J, Briles WE, Collisson EW. Memory T cells protect chicks from acute infectious bronchitis virus infection. Virology. 2003;306:376-84.

109. Seo SH, Pei J, Briles WE, Dzielawa J, Collisson EW. Adoptive transfer of infectious bronchitis virus primed alphabeta $\mathrm{T}$ cells bearing CD8 antigen protects chicks from acute infection. Virology. 2000;269:183-9.

110. Huang J, Cao Y, Du J, Bu X, Ma R, Wu C. Priming with SARS CoV S DNA and boosting with SARS CoV S epitopes specific for $\mathrm{CD} 4+$ and $\mathrm{CD} 8+\mathrm{T}$ cells promote cellular immune responses. Vaccine. 2007;25:6981-91.

111. Gupta V, Tabiin TM, Sun K, Chandrasekaran A, Anwar A, Yang K, Chikhlikar P, Salmon J, Brusic V, Marques ET, Kellathur SN, August TJ. SARS coronavirus nucleocapsid immunodominant $\mathrm{T}$ cell epitope cluster is common to both exogenous recombinant and endogenous DNA-encoded immunogens. Virology. 2006;347:127-39. 